\title{
Childhood Malignant Penile Neoplasm
}

National Cancer Institute

\section{Source}

National Cancer Institute. Childhood Malignant Penile Neoplasm. NCI Thesaurus. Code C118821.

A rare malignant neoplasm of the penis that occurs during childhood. 